\title{
高齢者に対する腰痛予防を目的とした8週間の 体幹エクササイズの効果 \\ 一エクササイズの筋持久力に与える効果一 \\ The Effect of 8 Weeks of Trunk Exercises for Prevention of Low Back Pain on Elderly People -Effect on Trunk Back Muscle Endurance-
}

$\begin{array}{lll}\text { 鈴木 哲1,2) } & \text { 栗木 鮎美1) } & \text { 石部 豪3) } \\ \text { 元平 智子4) } & \text { 高橋 正弘 }{ }^{1)} & \text { 楢崎 慎二 } \\ \end{array}$

TETSU SUZUKI, RPT ${ }^{1,2)}$, AYUMI KURIKI, RPT ${ }^{1)}$, Go ISHIBE ${ }^{3)}$, TOMOKO MOTOHIRA, RPT ${ }^{1)}$, MASAHIRO, TAKAHASHI, RPT ${ }^{1)}$, SHINJI NARAZAKI, MD ${ }^{5}$

1) Department of Rehabilitation, Kasaoka Daiichi Hospital: 1945 Yokoshima, Kasaoka, Okayama 714-0043, Japan. TEL +81 865-67-0211

2) Doctoral Program, Rehabilitation Graduate School of Health Science and Technology, Kawasaki University of Medical Welfare

3) Kasaoka Daiichi Hospital Health Care Center

4) Yuai Elder Healthcare Facility

5) Department of Orthopaedic Surgery, Kasaoka Daiichi Hospital

Rigakuryoho Kagaku 24(2): 221-226, 2009. Submitted Oct. 3, 2008. Accepted Nov. 13, 2008.

ABSTRACT: [Purpose] We examined the effect of trunk exercise for prevention of low back pain on trunk back muscle endurance of elderly people. [Subjects] Twenty-four people (74 \pm 5.1 years old) participated in this study. They were assigned to an exercise group or a control group. [Methods] The endurance parameters included the holding time of the Trunk Holding Test (THT) and electromyographic fatigability (IMF, MF-Slope) was also evaluated. [Results] Although a significant change in electromyographic fatigability was not observed after eight weeks of exercise in either group, THT increased significantly only in the exercise group. [Conclusion] The results suggest that the exercises conducted in this study were effective for improvement of THT that is one of the risk factors for low back pain.

Key words: elderly people, trunk back muscle endurance, trunk exercise

要旨：［目的］高齢者に対し, 腰痛予防を目的に体幹エクササイズを実施し, その効果を体幹背部筋の筋持久力か ら検討した。[対象］高齢者24名（74 \pm 5.1 歳）で, エクササイズ群（Exe群）13名とコントロール群（Con群）12名 の2群に分けた。[方法］筋持久力をTrunk Holding Testの保持時間（THT）と腰部多裂筋の筋電図学的筋疲労から評 価した。[結果] 8 週後, 2 群とも筋電図学的筋疲労に有意な変化はなかったが, THT は Exe群においてのみ有意に 向上した。[結語]実施したエクササイズによる腰痛のリスクファクターであるTHTの保持時間向上効果が示唆された。 キーワード : 高齢者, 体幹筋持久力, 体幹エクササイズ

1)笠岡第一病院リハビリテーション科 : 岡山県笠岡市横島1945（テ714-0043）TEL 0865-67-0211

2) 川崎医療福祉大学大学院 医療技術学研究科リハビリテーション学専攻博士後期課程

3) 笠岡第一病院健康管理センター 4 )介護老人保健施設ゆうあい リハビリテーション科 5 ) 笠岡第一病院 整形外科

受付日 2008年10月3日＼cjkstart受理日２008年11月13日 


\section{I.はじめに}

我が国の1ケ月の腰痛有病率は，30～60 歳代で男女 ともに約 $30 \% ， 70$ 歳代の男性は $28 \%$ ，女性は $47 \%$ と， 幅広い世代で腰痛は多い1)。また原因の不特定性, 高い 再発率 ${ }^{2)}$ から, 高齢者の ADL を慢性的に低下させる一 因となっている。高齢者は若年者に比べ身体機能の予 備力も低く, 腰痛による短期間の活動性低下や臥床に よっても，容易に廃用症候群を引き起こす。そのため 高齢者に対する一次的 -二次的な腰痛の予防や, 腰痛 後の効果的な治療が重要である。

腰痛に関寸る研究の中には, 体幹背部筋の筋持久力

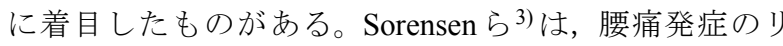
スクファクターの一つとして，体幹背部筋の筋持久力 評価法として広く利用されている Trunk Holding Test (THT) ${ }^{4-6)}$ の保持時間の低下を挙げている。さらに腰痛 既往者においても THTの保持時間の低下が報告されて いる7)。また近年, 客観的な筋持久力の評価法として筋 電図が用いられるようになり, THTの保持時間と腰部 多裂筋における筋電図学的筋疲労との相関が報告され ている6)。加えて, 腰部多裂筋の筋萎縮は腰痛の再発率 に相関することも報告され 8$)$, 一次的・二次的な腰痛予 防の観点からも体幹背部筋の筋持久力改善の必要性は 高い。

そのため多くの研究者が体幹背部筋の筋持久力の 向上を目的としたエクササイズの効果を報告している が4,9-11)，高齢者を対象としたものはみあたらない。さ らにそれらのエクササイズの負荷量は中等度〜高負荷 と様々である。一般にエクササイズは高負荷であれば その効果も高いとされる。しかしLatham ら ${ }^{12) や E t t i n g e r ~}$ ら 13) は，高齢者に対する高負荷エクササイズによるリ スクの増大と継続性の低さを指摘している。そこで中 等度の負荷でエクササイズを実施し，高齢者の体幹背 部筋の持久力向上がみられれば，エクササイズ中のリ スクも低くコントロールでき, 高齢者の腰痛予防や腰 痛後の運動療法に有用であるといえるだろう。

またバランス能力の低下も腰痛のリスクファクター の一つとして報告され ${ }^{14)}$, 腰痛後の運動療法や腰痛予 防エクササイズによるバランス能力の向上が求められ る。加えて, 近年, 脊椎疾患治療の患者立脚型アウト カムとして健康関連QOLを評価することが推奨されて (る15)。

今回, 我々は高齢者に対し腰痛予防の観点から, 体 幹背部筋持久力・バランス能力・健康関連 QOL $の$ 向上 を目的に 8 週間の体幹エクササイズを実施した。そし
てエクササイズの効果を体幹背部筋持久力，バランス 能力, 健康関連 QOL の観点から検討した。ここでは, 実施したエクササイズの体幹背部筋持久力に与える効 果について述べる。

\section{II. 対象と方法}

\section{1. 対象}

対象は, 地域で独立した生活を営む高齢者 24 名（男

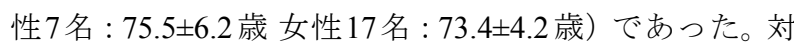
象者は, 本院と本院併設のスポーツジムにてポスター・ パンフレット・口頭での勧誘にて集めた。対象者を, エ クササイズに参加したエクササイズ群13名(男性4名 女 性9名）と, 測定調査のみに参加したコントロール群 11 名（男性3名女性8名）の2群に分類した。過去 3 ケ月以 内の腰痛既往者, 神経学的徵候のあるもの, 極端な脊 椎の変形のある者は事前に除外した。また医学的に運 動が適さないと判断された者も除外対象とした。事前 に, 全ての対象者に研究の趣旨・方法・リスクを説明 し同意を得た。また本院の倫理委員会の許可を得た。

\section{2. 方法}

評価項目は，対象者の属性，体幹背部筋の筋持久力 の 2 項目とした。対象者の属性はエクササイズ期間前 に 1 回調査した。体幹背部の筇持久力はエクササイズ 期間前・ 8 週後の計 2 回評価した。

対象者の属性は, 年歯, 性別, 身長, 体重の 4 項目を 調査した。

体幹背部筋の筋持久力として，THT の保持時間と， テスト施行時における腰部多裂筋の筋電図学的筋疲労 を評価した。

THT は Moffroid らの研究4)を参考に行った。対象者は 高さ $20 \mathrm{~cm}$ 程度の台上で腹臥位になり, 両側の上前腸骨 棘を結ぶ線まで上部体幹を床上へ下ろし，台と骨盤・ 下腿をベルトで固定した。検者の合図と共に，体幹を 下肢と一直線になるように伸展させその肢位を保持さ せた。検者はその際の保持時間をストップウォッチに て最大 3 分間計測した。測定終了は, 頭部の摇れ幅が上 下約 $5 \mathrm{~cm}$ になった時点，または本人がその肢位をこれ 以上保持できないと訴えた時点とした。頭部の摇れ幅 は床に垂直に設置したメジャーを使用し，検者の目視 により計測した。

筋電図学的筋疲労の指標の測定・算出は, 先行研究 6,9$)$ を参考に以下の手順で行った。まずTHT時の腰部多裂筋 の筋活動を, 表面筋電図 (VitalRecorder 2 : キッセイコム 
テック株式会社製）を使用し測定した。電極はL5の側方 かつ後上腸骨棘と L1-2 間の 2 点を結ぶ線と平行に筋腹上 に, アース電極は上前腸骨棘上に設置した。電極間距離 は2 cm, バンドパスフィルターは $10 〜 500 \mathrm{~Hz}$, サンプリ ング周波数の設定は $1,000 \mathrm{~Hz}$ とした。検者は被験者が安 定した体幹伸展保持を行った時点で筋電図の測定を開始 した。本研究の対象者は高齢者であり長時間のTHTの保 持が困難なものも予想されたため, Roy らの研究9)を参 考に測定時間は 30 秒間とした。筋電図の解析には, BIMUTAS II（キッセイコムテック株式会社製）を使用 した。そして先行研究6)に従い, 測定開始からの筋活動 に対し，1秒毎の周波数解析（高速フーリエ変換：1024point）を行い, その後回帰直線を算出し, 直線のY切片 をInitial Median Frequency（IMF），直線の傾きをMedian Frequency Slope（MF-Slope）とした。一般に Type 1 は低 周波帯に, Type 2 は高周波帯に対応するとされ, 筋線維 のタイプによりパワースペクトルは変化する。つまり筋 持久力に関与する Type 1 の比率が高いほどIMFは低い值 となる。また筋疲労時には, 筋疲労前に比べ, 高い周波 数成分が減少し低い周波数成分が増加するため周波数全 体では低下する。そのため筋持久力が低いほど, MFSlope は急な傾きを示すことになる。

エクササイズは 8 週間実施した。ACSMのガイダン ス 17,18) を参考に，エクササイズは週に2回実施し，エ クササイズ実施日の間隔は最低1日空けることとした。 内容は, ストレッチ, 体幹筋持久力エクササイズ, バ ランスエクササイズから構成され, 1 回の所要時間は $30 \sim 45$ 分間であった。バランスエクササイズは 4 週 後から導入した。全てのエクササイズは, 運動指導士・ 理学療法士の監視・指導のもとに実施した。

ストレッチは, ウォームアップ・クールダウンを目 的に, エクササイズの開始時, また終了時にそれぞれ $5 \sim 10$ 分間行った。対象筋は, 体幹・下肢筋とし, 静的 ストレッチにて実施した。

体幹筋持久力エクササイズの負荷量は以下の手順で 決定した。まずエクササイズ期間前に, 各被験者に対 し腰部多裂筋の最大随意収縮時 (Maximal Voluntary Contruction : MVC) の筋活動と, 図 1 に示した 4 種類の エクササイズ時における筋活動を測定した。使用した 筋電図, 筋電図解析ソフト, 電極貼付部位, フィルター の設定等は, 筋電図学的筋疲労の指標の測定 - 算出時 と同様であった。MVC測定は, 前述のTHTの肢位にて, 被験者に検者による両側肩甲骨部への抵抗下で最大随 意収縮の体幹伸展をおこなわせ，その際の筋活動を測 定した。4種類のエクササイズ時における筀活動の測定
は, 図 1 に示した各エクササイズ時の肢位を保持し, そ の際の筋活動を測定した。各筋活動の測定は2回実施 し，測定時間は5秒間とした。また各測定は，理学療法 土の指導のもと適度な練習を行った後に実施し, 疲労 の影響を避けるため各測定間には2〜3分程度の休息を 挟んだ。その後, MVC, 各エクササイズ時の筋活動を 全波整流し, 中間 3 秒間の平均積分值を算出した。また 偏りを軽減するために, 測定 1 回目と 2 回目の平均值を 算出し, MCV, 各エクササイズ時の筋活動とした。次 に，被験者ごとに各エクササイズ時の腰部多裂筋の筋 活動を, MVCを基準に正規化し\%MVCを算出した。そ して, 4 種類のエクササイズの中から腰部多裂筋の筋活 動が 40 〜 60\%MVCとなるものを, 実施エクササイズと して被験者ごとに設定した。そして，ストレッチの後 に $20 \sim 25$ 分間実施した。エクササイズ中に体幹が屈 曲・伸展・回旋の最終域になる事は腰部の関節や筋へ の過度なストレスを生じさせるため, 避けたほうがよ いとされている19)。そのためエクササイズは, 骨盤中 間位での等尺性収縮にて, 腰部に中等度の疲労感(自覚 的運動強度のレベルが $12 \sim 13$ : ややきつい）を感じる まで, もしくは最大 1 分程度, 各肢位を保持することを 基本とした。これを 1 セットとし，10〜 15 セット実施 した。また各セット間に 30 秒〜 1 分程度の休息をとった。 バランスエクササイズは，4週間後から導入し，8週 間後までの 4 週間, 等持久力エクササイズ後に $10 \sim 15$ 分間実施した。内容は，バランスボールを使用し，バ ランスボール上で座位になり, 片脚を膝屈曲位で挙上 する, 腰を回旋させる, ボール上で弾む, ボール上で のブリッジなどの運動を実施した（図2）。

統計学的処理にはStat View（ver.5.0）を使用した。エ クササイズ期間前におけるエクササイズ群とコントロー ル群の差は対応のないt検定により比較した。エクササ イズ効果の検討は, 各群内にてエクササイズ期閒前と 8 週後の各評価項目を対応のある $\mathrm{t}$ 検定により比較し た。さらに2 群間におけるエクササイズ期間前・8週後 の各評価項目の数值・変化率を対応のない $\mathrm{t}$ 検定によ り比較した。それぞれ有意水準は $5 \%$ 末満とした。また 各データの検討は研究から脱落したものを除いて行っ た。

\section{III. 結 果}

エクササイズ期間前, 属性, 筋持久力の各測定項目 においてエクササイズ群とコントロール群の間に有意 な差はみられなかった（表1）。 

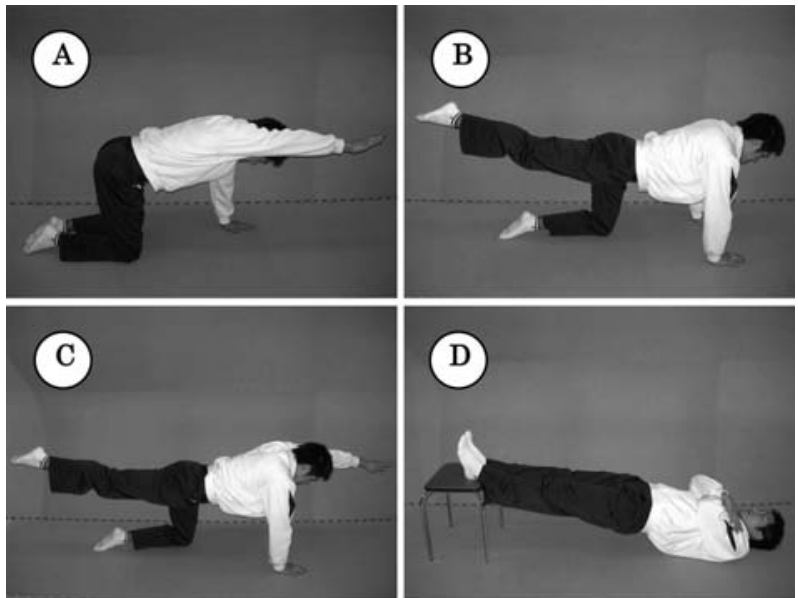

図1 体幹筋持久力エクササイズ

A : 四つ這い片手挙上保持 B : 四つ這い片脚挙上保持

$\mathrm{C}$ : 四つ這い片手片脚挙上保持 $\mathrm{D}:$ ブリッジ
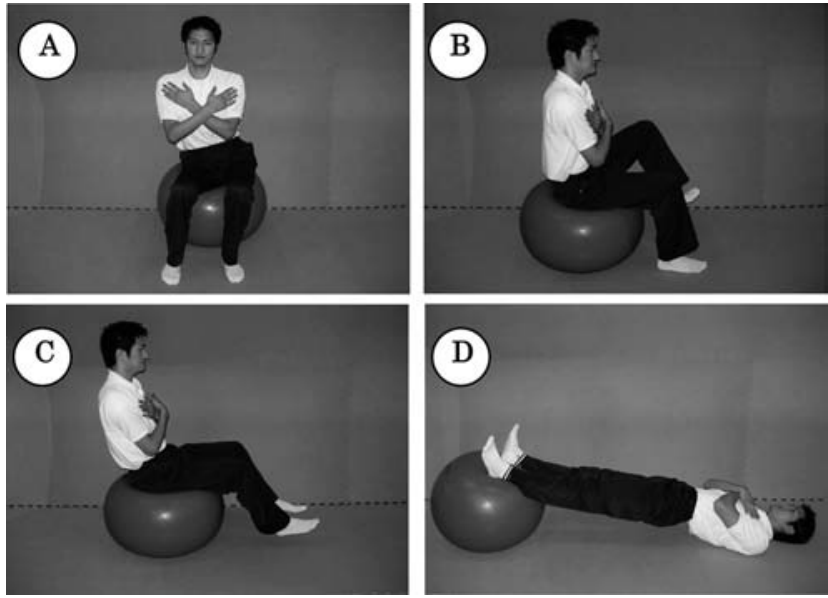

図2 バランスボールエクササイズ

$\mathrm{A}$ : 腰部前後・左右回旋運動 $\mathrm{B}$ : 片脚挙上保持

$\mathrm{C}$ : 両脚挙上保持 $\mathrm{D}$ : ボール上ブリッジ

表1 エクササイズ期間前におけるエクササイズ群とコントロール群の比較

\begin{tabular}{|c|c|c|c|c|}
\hline & & $\begin{array}{c}\text { エクササイズ群 } \\
(\mathrm{n}=10)\end{array}$ & $\begin{array}{c}\text { コントロール群 } \\
(\mathrm{n}=11)\end{array}$ & 2 群比較 \\
\hline \multirow[t]{3}{*}{ 対象者の属性 } & 年齢（歳） & $74.5 \pm 4.9$ & $73.4 \pm 5.4$ & NS \\
\hline & 身長（cm） & $154.0 \pm 7.8$ & $151.5 \pm 5.2$ & NS \\
\hline & 体重（kg） & $54.2 \pm 5.1$ & $56.8 \pm 8.1$ & NS \\
\hline \multirow[t]{3}{*}{ 筋持久力 } & IMF（Hz） & $107.9 \pm 26.0$ & $91.0 \pm 15.5$ & NS \\
\hline & MF-Slope & $-0.49 \pm 0.41$ & $-0.43 \pm 0.33$ & NS \\
\hline & Time (s) & $66.7 \pm 48.3$ & $59.9 \pm 34.3$ & NS \\
\hline
\end{tabular}

Mean \pm SD Times : THT保持時間

NS : not significant

2 群ともエクササイズ期間前後における IMF，MFSlopeに有意な変化はみられなかった。THTの保持時間 は, エクササイズ群ではエクササイズ期間前と比べ 8 週 後に有意に増加したが，コントロール群では有意な変 化はみられなかった。またエクササイズ群におけるTHT の保持時間の変化率はコントロール群に比べ大きい值 を示し，2群間に有意な差がみられた（表2）。

\section{IV. 考 察}

エクササイズ期閒前, 属性, 筋持久力の各測定項目 においてエクササイズ群とコントロール群との間に有 意な差はみられなかった。両群の各測定項目は近似し ていたが，各項目の標準偏差が大きいため有意差が認 められない可能性も考えられた。

8 週後, 両群ともIMF, MF-Slopeには有意な変化がな
かったが，エクササイズ群においてはTHT の保持時間 が有意に向上したことから，実施したエクササイズに よる高齢者の体幹背部筋の筋持久力向上効果が示され た。

エクササイズ期間後, 両群とも IMF, MF-Slope に有 意な変化がなかった理由として以下のことが考えられ る。Roy ${ }^{9) や K a n k a a n p a a ~} ら^{10)}$ は, 若年者を被験者とし て，高負荷なエクササイズを実施し，それぞれ 10 週間 後, 12 週間後に, IMF, MF - Slope の有意な改善を報告 している。Mannion ら 11,20) は, 本研究と類似した中等度 の負荷量で, 若年者の体幹背部筋に対し3ケ月間エクサ サイズを実施した結果, IMF, MF-Slopeの改善や筋肥 大・筋組成の変化はみられず, THT の保持時間と腰部 春柱起立筋の筋活動・筋力が向上したと報告している。 本研究で対象とした高齢者は若年者と比べ, 筋肥大に 関与するサテライト細胞や運動単位数が減少し, 循環 
表2 体幹背部の筋持久力に対するエクササイズ効果

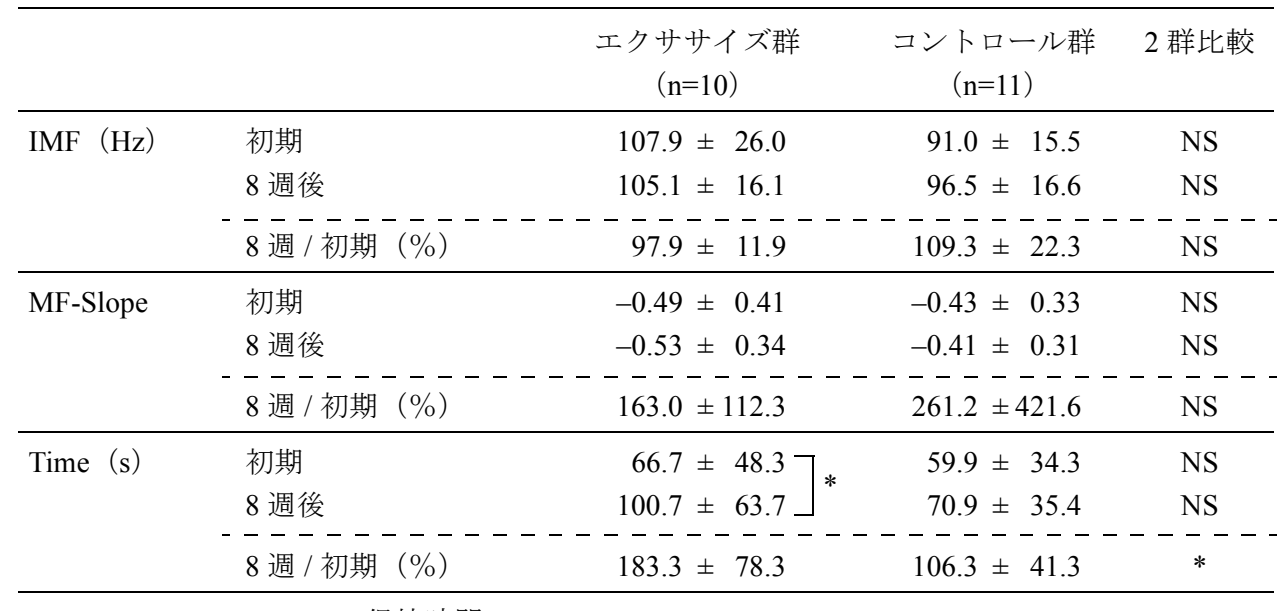

Mean \pm SD Times : THT 保持時間

NS : not significant $\quad *: \mathrm{p}<0.05$

や成長ホルモンなど内分泌系が低下している21)。その ため高齢者に対し中等度の負荷にてエクササイズを実 施し, 腰部多裂筋の筋肥大・筋組成の変化にともなう IMF，MF-Slope の改善効果を得るには，8週間では不十 分であり, より長期間のエクササイズの実施が必要な 可能性が考えられた。

8 週後, エクササイズ群にみられた THT の保持時間の 向上は, 神経因子による筋力の向上が関与していると考 える。 Mannion ら ${ }^{11,20)}$ は, 前述の研究の中で, エクササ イズによる腰部脊柱起立筋の筋活動と筋力の向上効果, およびそれらの有意な正の相関を報告し, THTの保持時 間の増加は神経因子による筋力向上が関与していると 考察している。さらにTHTにおける体幹伸展は, 被検筋 として設定した腰部多裂筋だけでなく, 股関節周囲筋や 他の脊柱起立筋群の活動に影響を受ける22)。今回, 筋力 や腰部多裂筋以外の筋に対する効果を検討していない ため定かでは無いが, THTの保持時間の向上に, 腰部多 裂筋を含む複数の筋群の筋活動や協調性の向上が関与 した可能性がある。

THT は, 再現性や信頼性, またより客観的な筋持久 力評価法である周波数解析を用いた筇電図学的筋疲労 の指標との有意な相関も報告されており 4-6), 体幹背部 筋の筋持久力評価法として広く利用されている。Sorensen らは THT を使用し体幹背部の筋持久力を評価し, THT の保持時間の低下は腰痛発生のリスクファクターであ る事を報告している3)。そして腰痛既往者は, 健常者と 比べTHTの保持時間が低下していることも報告され7), 腰痛予防・治療として体幹筋持久力の向上が重要とさ
れている。一般にエクササイズは高負荷であれば効果 も高いが, Latham ら ${ }^{12) や E t t i n g e r ~ ら ~}{ }^{13)}$ は, 高齢者に対す る高負荷エクササイズによるリスクの増大と継続性の 低さを指摘している。本研究では中等度の負荷（40～ $60 \% \mathrm{MVC})$ で 8 週間の体幹エクササイズを実施し, 腰 痛後の治療や予防に関与寸る THT の保持時間の向上効 果を示した。これは実施したエクササイズの腰痛後の 治療や予防への適応の可能性を示唆している。

謝辞 本研究に対し多大なるご協力を賜った被験者の 皆様および笠岡第一病院職員の皆様, そしてご指導を 賜った川崎医療福祉大学の渡邊進先生に深謝いたしま す。

\section{引用文献}

1) 福原俊一：RDQ日本語版マニュアル。福原俊一 (編), 医療 文化社, 東京, 2004, pp28-31.

2) Troup JDG, Martin MLJW: Back pain in industry-a prospective survey. Spine, 1981, 6: 61-69.

3) Sorensen FB: Physical measurements as risk indicators for low back trouble over a one-year period. Spine, 1984, 9: 106-119.

4) Moffroid MT, Haugh LD, Haig AJ, et al.: Endurance training of trunk extensor muscles. Phys Ther, 1993, 73: 10-17.

5) Alaranta H, Hurri H, Heliovaara M, et al.: Non-dynamometric trunk performance tests: reliability and normative data. Scand J Rehab Med, 1994, 26: 211-215.

6) Ng JKF, Richardson CA: Reliability of electromyographic power spectral analysis of back muscle endurance in healthy subjects. Arch Phys Med Rehabil, 1996, 77: 259-264.

7) Nicolaisen $T$, Jorgensen K: Trunk strength, back muscle endur- 
ance and low back pain. Scand J Rehab Med, 1985, 17: 121-127.

8) Hides JA, Jull GA, Richardson CA: Long-term effects of specific stabilizing exercises for first-episode low back pain. Spine, 2001, 26: E243-E248.

9) Roy SH, Luca CJD, Emley M, et al.: Spectral electromyographic assessment of back muscle in patients with low back pain undergoing rehabilitation. Spine, 1995, 20: 38-48.

10) Kankaanpaa M, Taimela S, Airaksinen O: The efficacy of active rehabilitation in choronic low back pain. Spine, 1999, 24: 10341042.

11) Mannion AF, Taimela $S$, Muntener M, et al.: Active therapy for choronic low back pain — part1. Effects on back muscle activation, fatigability, and strength. Spine, 2001, 26: 897-908.

12) Latham NK, Anderson CS, Lee A, et al.: A randomized controlled trial of quadriceps resistance and vitamin $\mathrm{D}$ in frail older people : the frailty interventions trial in elderly subjects (FITTNESS). J Am Geriatr Soc, 2003, 51: 291-299.

13) Ettinger WH, Burns R, Messier SP, et al.: A randomized trial comparing aerobic exercise and resistance exercise with a health education program in older adults with knee osteoarthritis, the fitness arthritis and seniors trial (FAST). JAMA, 1997, 277: 25-31.

14) Takala E-P, Viikari-Juntura E: Do functional tests predict low back pain? Spine, 2000, 25: 2126-2132.
15) Bombardier C: Spine focus issue introduction : Outcome assessments in the evaluation of treatment of spinal disorders : summary and general recommendations. Spine, 2000, 25: 3097-3099.

16) 村上雅也, 荒川美穂, 川上康子・他：高齢者の意欲と生活動 作能力の関連. 理学療法一臨床・研究・教育, 2007, 14:58-62.

17) American College of Sports Medicine : ACSM's guidelines for exercise testing and prescription, 5th edition, Williams \& Wilkins, Baltimore, 1995, pp153-234.

18) American College of Sports Medicine: 運動処方の指針一運動負 荷試験と運動プログラム, 第7版. 南江堂, 東京, 2006, pp134269.

19) McGill SM : 腰痛一最新のエビデンスに基づく予防とリハビ リテーション一. 吉沢英造 (訳), ナップ, 東京, 2005, pp87128.

20) Mannion AF, Dumas GA, et al.: The influence of muscle fiber size and type distribution on electromyographic measures of back muscle fatigability. Spine, 1998, 23: 576-584.

21) 山崎俊明 : 高齢者の骨格筋機能と運動療法. PTジャーナル, 2007, $41:$ 13-23.

22) McKeon MD, Albert WJ, Neary JP: Assessment of neuromuscular and haemodynamic activity in individuals with and without chronic low back pain. Dynamic Medicine, 2006, 5: 6. 